\title{
El-Fayah
}

JURNAL BIOLOGI

Journal Homepage: http://ejournal.uin-malang.ac.id/index.php/bio/index

e-ISSN: 2460-7207, p-ISSN: 2086-0064

\section{Ethnobotanic of Pest Preventing Plants Oryza sativa L. by The Baduy Tribe Community in Leuwidamar District, Lebak Banten, Indonesia}

\section{Akhmad Bashori Alwi, Eko Budi Minarno, Azizatur Rahmah, Achmad Shonhaji, Robiatul Adawiyah}

Biology Department, Faculty of Science and Technology

Maulana Malik Ibrahim State Islamic University of Malang

*Corresponding author

Email: budi_minarno@bio.uin-malang.ac.id

DOI: 10.18860/elha.v8i1.10924

\begin{tabular}{l} 
A r t i c I e I n f o \\
\hline Article history: \\
Received 10 May 2020 \\
Received in revised form \\
13 June 2020 \\
Accepted 21 August 2020 \\
\hline Key Word: \\
Etnobotany \\
Baduy \\
Pest Preventing Plants \\
Rice Oryzasa sativa \\
Lebak Banten
\end{tabular}

\begin{abstract}
Baduy people have local wisdom about the use of plants, among others, as ingredients to prevent the presence of rice pests (Oryza sativa L.). the importance of these pest-preventing plants to produce allelopathy in order to prevent rice pests (Oryza sativa L.). To find out what plants are used by Baduy people, this research is necessary. Exploration of pest control plants is carried out using the PEA (Participatory Ethnobotanical Appraisal) approach, besides that it also uses survey methods and open interview techniques. The results of the survey were 21 non-key informants and 5 key-informants from the Outer Baduy community and 12 non-key informants and 1 key informant from the Inner Baduy community, 35 species from 22 plant families were used in all rituals to prevent the presence of rice pests. . Plants that have similarities in usage by the Outer Baduy and Inner Baduy are Bamboo Wuluh leaves (Schyzostachyum iraten), Noni leaves (Morinda citrifolia), Bemban (Donax canniformis), Walang leaves (Achasma walang Val.) And Langge leaves (Homalomena cordata). The percentages of plant organs used to prevent the presence of rice pests are leaves (77\%), stems (17\%) and fruit (6\%). The method of processing plants as raw material for rice pest prevention ingredients is to cut them in small volumes / chop (39.74\%), pound (52.56\%), ferment (3.85\%) and burn (3.85\%). Baduy rituals in preventing the presence of rice pests include 5 types namely Ngubaran Samara Pungpuhunan ("Treatment" of Main Plants), Ngubaran Cangkudu ("Treatment" of Noni), Ngubaran Bangban ("Treatment" of Bemban / Donax canniformis), Fumigation, and Leuit Susumpingan (Lumbung offerings).
\end{abstract}




\section{INTRODUCTION}

Oryza sativa $\mathrm{L}$. is a staple food ingredient for more than 95 percent of Indonesia's population (Satria and Erwin, 2017). So that it becomes the main agricultural commodity in Indonesia. Based on this, domestic rice production is a benchmark for food availability for Indonesia. The problem faced in the cultivation of $O$. sativa $L$. is Plant Pest Organisms (PPO). In general, farmers use pesticides to solve pest problems in O. sativa $\mathrm{L}$. and prevent crop failure. However, as the negative impact caused by pesticides is pollution on agricultural land which degrades the soil ecosystem(Suciati et al., 2016). In addition $39 \%$ of farmers who use chemical pesticides experience several health problems.

The phenomenon of the negative impact of pesticides indicates that the negative impacts caused are more than the positive impacts. Thus, it is necessary to find other alternatives as a solution to the problem of $O$. sativa L. pests, in order to save the agricultural environment ecosystem. It is important to focus on alternative solutions to the problem of O. sativa L. plant pests to be directed at a larger goal, namely environmental conservation for the sustainability of the agriculture. An alternative that can be done is to learn from traditional tribes who have local wisdom in agricultural management, especially in dealing with the pest O. sativa L.

One of the tribes in Indonesia that has local wisdom in agricultural management, especially in the aspect of the pest $O$. sativa $L$. is the Baduy tribe. The Baduy people is divided into two groups, the Outer Baduy, which is more adaptive to modern life, and the Inner Baduy, which is still very strong in carrying out the traditions and customs of their ancestors. (Kameswari and Yusup, 2020) argued that the Baduy has the principle of implementing the concept of natural equilibrium in agricultural environmental ecosystems for the sustainability of agriculture-based life. The Baduy has the character of preventing the intrusion of non-natural chemical compounds such as chemical fertilizers, synthetic growth regulators, and chemical pesticides into the environmental ecosystem and more specifically to the agricultural ecosystem. The Baduy maintains the concept of environmental sustainability.

In connection with agricultural management in the aspect of solutions to $O$. sativa L. pests, the Baduy uses the herbs around them to prevent the presence of pests. In the Baduy, there are traditional activities or rituals known by the name of the Sundanese language, namely "Ngubaran Pare" or "Treating Rice". In this ritual, the Baduy uses plant ingredients to prevent the presence of $O$. sativa $L$ pests. It is suspected that the active compounds contained in herb plants can prevent the presence of rice pests.

Based on the phenomenon of the use of herbs by the Baduy community, it can be argued that there is a relationship between humans and plants for the benefit of life. The relationship between humans and plants in the form of using plant ingredients to prevent the presence of pests on O. sativa L. was included in the Ethnobotany study. The discussion about the relationship between ethnobotany and how a tribe behaves is an interesting topic to study.

\section{MATERIALS and METHODS}

This research is a descriptive exploratory research with survey methods and open interview techniques. The approach in this research is PEA (Participatory Ethnobotanical Appraisal) in the form of the involvement of researchers in the life of the Baduy community related to the use of plant ingredients to prevent the presence of PEA (Participatory Ethnobotanical Appraisal) rice plant pests. This research was conducted in September 2018 which is located in the residence of the Outer Baduy and Inner Baduy. The Outer Baduy tribe originates from Kadu Ketug, Kadu Kaso and Cipondok villages, while the Inner Baduy originates from Cibeo Village, Leuwidamar 
District, Lebak Regency, Banten Province. The population in this study were the indigenous peoples of the Outer Baduy and Inner Baduy.

The sample in the study (respondents) consisted of key informants and non-key informants. The key informant is a traditional leader in the Baduy community. In the Outer Baduy, there are 29 respondents consisting of 5 key informants and 21 non-key informants. The Inner Baduy, there are 13 respondents consisting of 1 key informant and 12 non-key informants. The sampling technique was.

The data collection process in research uses the Open Interview Technique for aspects of plant types and plant organs using purposive sampling technique used as ingredients to prevent the presence of rice pests, how to use plant ingredients, The

Table 1. List of Presence of Rice Pests interview used Sundanese and Indonesian language. and ways of conserving or preserving plants, ingredients for preventing pests, as well as conservation of local wisdom to prevent the presence of pests O.sativa $\mathrm{L}$.

\section{RESULTS}

Types of Plants Potions to Prevent the Presence of Rice Pests by the Baduy Community

The plant ingredients for preventing the presence of rice pests (Oryza sativa L.) used by both the Outer Baduy and Inner Baduy Tribe consist of 22 families and 35 species as shown in Table 1

\begin{tabular}{|c|c|c|c|}
\hline Family & Species & Family & Species \\
\hline \multirow[t]{3}{*}{ Poaceae } & Schizostachyum iraten & Euphorbiaceae & Phyllanthus niruri L \\
\hline & $\begin{array}{l}\text { Gigantochloa } \\
\text { pseudorundinaceae }\end{array}$ & Sellaginellaceae & Sellaginella sp. \\
\hline & Cymbopogon nardus & Cyperaceae & Cyperus rotundus \\
\hline \multirow[t]{2}{*}{ Liliaceae } & Cordilyne terminalis & Piperaceae & Piper betle \\
\hline & Allium tuberosum & & Piper aduncum \\
\hline \multirow[t]{5}{*}{ Arecaceae } & Pinanga kuhlii & Myrtaceae & Syzgium polyanthum \\
\hline & $\begin{array}{l}\text { Daemonorops } \\
\text { melanochaetes }\end{array}$ & Rubiaceae & Morinda citrifolia \\
\hline & Arenga porphyrocarpa & Rutaceae & Citrus maxima \\
\hline & Arenga pinnata & Malvaceae & Durio zibethinus \\
\hline & Homalomena cordata & Melastomaceae & Melastoma candidum \\
\hline \multirow[t]{2}{*}{ Marantaceae } & Donax canniformis & Lamiaceae & $\begin{array}{l}\text { Plectranthus } \\
\text { scutellarioides }\end{array}$ \\
\hline & Halopegia blumei & & Staurogyne elongate \\
\hline Family & Species & Family & Species \\
\hline Moraceae & Artacorpus elastica & Costaceae & Costus speciosus \\
\hline Asteraceae & Tagetes erecta & Apocynaceae & Hoya diversifolia \\
\hline \multirow[t]{7}{*}{ Zingiberaceae } & Amomum maximum & & \\
\hline & Kaempferia galanga & & \\
\hline & Zingiber officinale & & \\
\hline & Apinia malaccensis & & \\
\hline & Alpinia galanga & & \\
\hline & Eringium feotidum & & \\
\hline & Zingiber cassumunar & & \\
\hline
\end{tabular}

From the results of observations and surveys conducted while in the Badui region, the percentage of organ use data was obtained as follows: the percentages of plant 
organs used to prevent the presence of rice pests are leaves (77\%), stems (17\%) and fruit (6\%). The method of processing plants as raw material for rice pest prevention ingredients is to cut them in small volumes / chop (39.74\%), pound $(52.56 \%)$, ferment (3.85\%) and burn (3.85\%).

\section{Ethnobotany and Rituals of Giving Plant Potions to Prevent Plant Pests of Oryza sativa L.)}

There are 5 kinds of ways to prevent the presence of rice pests carried out by the Baduy tribe including Ngubaran Samara Pungpuhunan ("Treatment" of Main Plants), Ngubaran Cangkudu ("Treatment" of Noni), Ngubaran Bangban ("Treatment" Bemban), Fumigation, and Susumpingan Leuit (Offerings Barn).

\section{a. Rituals Ngubaran Samara Pungpuhunan}

This activity is carried out at the age of 40 HST (Day After Planting). The most widely used plant is Bamboo Wuluh (Tamiyang) (Schyzostachyum iraten) which is included in the Poales order. Each of these ingredients is cut into smaller volumes, mixed until homogeneous, and spread over the rice fields.

The Poales family has a rather long and stiff leaf type, when squeezed will release the essential oil content in the form of Oleum citronale (Tjitrosoepomo, 2010). Rice pests that tend to be present during the Ngubaran Samara Pungpuhunan period are Walang Sangit (Leptocorisa oratorius) and Pest Ganjur (Orseolia oryzae). According to (Yunianti, 2016) essential oils that enter the respiratory system of Walang Sangit (Leptocorisa oratorius) and cause respiration inhibitors. Respiration disorders in the stink bug is thought to last for 3 to 5 days, so that during that time the grasshopper will die. This ritual is very necessary for the process of saving the growth of Leptocorisa oratorius.

\section{b. The Cangkudu ritual}

This activity is carried out starting one week after the previous activity (Ngubaran Samara Pungpuhunan) or starting from the 4750 DAS. This activity is carried out by grinding the noni leaves mixed with other leaves (and dousing them with fermented palm water (Arenga pinnata), then spreading them over the rice fields. Noni (Morinda citrifolia) is used by both the Outer Baduy and Inner Baduy Tribe. Rice pests in this phase are Walang Sangit (Leptocorisa oratorius), Planthopper (Fulgoromorpha), Rats (Rattus norvegicus) and Grayak Caterpillars (Spedoptera litura). According to (Sari, Lubis and Pangestiningsih, 2013) armyworms (Spedoptera litura) that have eaten noni leaf extract have decreased appetite (antifeedant).

\section{c. Ritual Ngubaran Bangban}

The "Ngubaran Bangban" activity is carried out within 67-70 days of paddy age. Activities in the form of mixing bemban leaves (Donax canniformis) with the ingredients of Plectranthus scutellarides, Cymbopogon citratus, Cordyline terminalis, Daemonorops melanochaetes. Pinanga kuhlii which is pounded and then soaked with water from the red rice soaking.

This activity is carried out by both the Outer Baduy and Inner Baduy Tribe using the same plant, namely the Bemban leaf (D. canniformis). Pests that attack rice in the Ngubaran Bangban phase are Walang Sangit (L.oratorius), Wereng (Fulgoromorpha) and Uret (Lepidiota stigma). According to (Kartasapoetra, 1990) L. stigma larvae will hatch around November and grow about 2 months later, and will eat the roots and stems of plants. According to (Rachmawati and Danar, 2010) the content of active saponin compounds in the Bemban plant (D. canniformis) has an inhibiting effect on the digestion of leafhoppers (Fulgoromorpha). 


\section{d. Ritual Fumigation}

The next activity is fumigation which is carried out when the rice is about two months old or around 60 DAS. In the process of preventing rice pests, this is done by burning a mixture of plant ingredients. Plants that were burned were walang leaves (Eringium feotidum Val.) And bamboo apus (Gigantochloa pseudoarundinaceae). .

According to respondents, rice pests in this phase were planthopper (L. oratorius), Walang Sangit (Fulgoromorpha) and Sparrow (Estrildidae). According to (suryaningsih and hadisoeganda, 2004) the leaves of Walang (Eringium feotidum Val.) Have an odor that disturbs the senses of pests.

\section{e. Ritual Sesaji Lumbung (Leuit)}

This activity is carried out when the rice is stored in a barn (Sundanese: Leuit). This activity used Homalomena cordata, Artacorpus elastic, Costus speciosus, Hoya difersifolia, Cyperus pilosus, Piper betle, and Phyllantus niruri L. The herbs were made into four bunches and then placed in the 4 corners of the barn.

The same plant used by the Outer Baduy and Inner Baduy is Homalomena cordata. Pests that attack rice in this phase according to respondents are rats (Rattus norvegicus) and birds (Estrildidae). According to (Shah, 2002), prevention against pests can occur because of the aroma of essential oils.

\section{CONCLUSION}

Types of plants that are used by both the Outer Baduy and Inner Baduy are Wuluh Bamboo (Schyzostachyum iraten), Noni leaf (Morinda citrifolia), Bemban (Donax canniformis), Walang leaf (Eringium feotidum) and Langge leaf (Homalomena cordata). The plant organs used with the highest percentage were leaves (77.38\%). The method of processing plants into a herb to prevent rice pests with the highest percentage is the method of pounding $52.56 \%$ of all processing methods. Efforts to maintain the existence (conservation) of local wisdom to prevent rice pests are by directly involving family members from the preparation to the ritual of preventing rice pests, and being passed down from generation to generation.

\section{REFERENCES}

Kameswari, D. and Yusup, M. (2020) 'Kearifan Lokal Bercocok Tanam Pada Masyarakat Pedalaman Suku Baduy', $P$ rosidingseminarNasionalsai ns, p. 7 .

Kartasapoetra, G. (1990) Hama tanaman pangan dan perkebunan. Jakarta.

Rachmawati, D. and Danar (2010) 'pemanfaatan ekstrak tanaman parasit tali putri (cassytha filiformis I.) sebagai insektisida nabati pada hama wereng coklat (nilaparvata lugens)', p. 13.

Sari, M., Lubis, L. and Pangestiningsih, Y. (2013) 'Uji Efektivitas Beberapa Insektisida Nabati Untuk', (2337), p. 10.

Satria, B. and Erwin, M. (2017) '2228-Article Text-7585-1-10-20191021.pdf'. UUniversitas Tadulako. Available at: http://jurnal.untad.ac.id/jurnal/index.ph p/AGROLAND/article/viewFile/8569/68 01.

Shah, $r$ (2002) 'Alternative Medicine'. Available at: http://www.geocity.com/ rainforest/aroma .htm I.

Suciati, F. et al. (2016) 'Pengaruh Pemberian Pestisida terhadap Transformasi Asam Fenolat serta Produksi $\mathrm{CO}_{2}$ dan $\mathrm{CH}_{4}$ pada Tanah Gambut', 40(1), p. 12.

suryaningsih, euis and hadisoeganda, widjaja (2004) 'Pestisida Botani untuk mengendalikan hama penyakit pada tanaman sayuran'.

Tjitrosoepomo, G. (2010) Taksonomi Tumbuhan Obat.

Yunianti, L. (2016) Yunianti, L. Uji Efektivitas Ekstrak Daun Sirih Hijau (Piper betle) Sebagai Insektisida Alami terhadap Mortalitas Walang Sangit (Leprtocarisa Acuta). Skripsi. Yogyakarta: Universitas Sanata Dharma. Universitas Sanata Dharma. 